\title{
Originals
}

\section{The Insulin Receptor on the Human Lymphocyte: Insulin-Induced Down-Regulation of 126,000 and 90,000 Glycosylated Subunits}

\author{
L.C. Harrison, A. Itin, M. Kasuga and E. Van Obberghen \\ Diabetes Branch, National Institute of Arthritis, Metabolism and Digestive Diseases, National Institutes of Health, \\ Bethesda, Maryland, USA
}

Summary. Cultured human lymphoblastoid B lymphocytes were surface-labelled with iodine ${ }^{125}$ and solubilized in $1 \%$ Triton $\mathrm{X}-100$ in the presence of protease inhibitors. After purification of labelled glycoproteins by elution from immobilized wheat germ lectin with $0.3 \mathrm{~mol} / 1 \mathrm{~N}$-acetyl-D-glucosamine, insulin receptors were quantitatively immunoprecipitated using IgG receptor auto-antibodies. The overall recovery of labelled glycoprotein was $0.02-0.04 \%$; analysis by sodium dodecyl sulphate-polyacrylamide gel electrophoresis and autoradiography under reducing conditions revealed two major bands with molecular weights of 126,000 and 90,000 , and a minor band of 67,000 daltons. The mobilities of both major receptor subunits were increased after treatment with neuraminidase. When lymphocyte receptor binding was 'down-regulated' before surface labelling, there was a concomitant decrease in the recovery of both the 126,000 and 90,000 subunits. These data indicate that 'down-regulation' of binding probably involves degradation of the receptor molecule.

Key words: Human lymphocytes, surface labelling, insulin receptors, auto-antibodies, receptor subunits.

The structure of the insulin receptor in rat tissues has been analysed after covalent affinity labelling, either by chemical cross-linking of ${ }^{125}$ I-insulin $[1,2]$ or by binding of photoreactive ${ }^{125}$ I-insulins [3-6]. These studies reveal a disulphide-linked oligomer of molecular weight $300-350,000$, a major reduced-binding subunit of $125-135,000$, and a variable subunit of 90,000 .

We have utilized polyclonal auto-antibodies to the insulin receptor, obtained from patients with se- vere insulin-resistant diabetes and the skin disorder acanthosis nigricans $[7,8]$ as probes of receptor function. Recently it was demonstrated directly that these auto-antibodies recognise the insulin binding subunits of the disulphide-linked oligomeric receptor [9]. In the present study we have used these auto-antibodies to isolate receptor subunits from ${ }^{125} \mathrm{I}$ - surface-labelled human lymphocytes and to examine the fate of these subunits after 'down-regulation' of insulin binding.

\section{Materials and Methods}

Porcine insulin (27.3 U/mg, lot QA 1312) was purchased from Elanco Products (Eli Lilly, Indianapolis, Indiana, USA); carrier free $\mathrm{Na}{ }^{125} \mathrm{I}$ and Triton X-100 from New England Nuclear, Boston, Massachusets, USA; lactoperoxidase (E.C.1.11.1.7) purified from milk (lot 39C-0108), leupeptin (lot 109C0335), phenylmethyl sulphonylfluoride, aprotonin (lot 10F0562) and 4-(2-hydroxyethyl)-1piperazine ethane sulphonic acid (Hepes) from Sigma, St. Louis, Missouri, USA; Bacitracin (lot 800695) from Calbiochem, San Diego, California; neuraminidase (E.C.3.2.1.19, lot 56E542) from Worthington, Freehold, New Jersey, USA; human IgG and wheat germ lectin-agarose from Miles-Yeda, Kankakee, Illinois, USA; and Protein A-Sepharose from Pharmacia, Piscataway, New Jersey, USA. Fetal calf serum and RPM1-1640 media were from Flow Laboratories, McLean, Virginia, USA; Antiserum to human IgG was raised in sheep to a titre of $2.5 \mathrm{mg} / \mathrm{ml}$. Reagent grade chemicals for sodium dodecyl sulphate-polyacrylamide gel electrophoresis (SDS-PAGE) were all purchased from Bio-Rad, Richmond, California, USA. Kodak XR-2 film and Dupont Cronex Lighting-Plus $X$-ray enhancing screens were purchased from Picker Corporation, White Plains, New Jersey.

\section{Surface Labelling of IM-9 Lymphocytes}

Human B lymphoblastoid cells of the IM-9 line were grown in continuous culture at $37^{\circ} \mathrm{C}$ in RPMI 1640 medium supplemented with $10 \%$ fetal calf serum, $25 \mathrm{mmol} / 1$ Hepes, and $2 \mathrm{mmol} / 1$ glutamine. After washing three times in phosphate buffered saline $(\mathrm{pH} 7.5$, PBS), the cells were iodinated as previously described [10]. Briefly, $100 \mathrm{ml}$ of PBS, at $24^{\circ} \mathrm{C}$, contained approximately $1 \times 10^{6} \mathrm{cells} / \mathrm{ml}$, $5 \times 10^{-7} \mathrm{~mol} / 1 \mathrm{Nal}, \mathrm{Na}{ }^{125} \mathrm{I}(1 \mathrm{mCi})$, and lactoperoxidase $(2 \mathrm{mg})$, to 
which $100 \mu \mathrm{l}$ of $10^{-3} \mathrm{~mol} / 1 \mathrm{H}_{2} \mathrm{O}_{2}$ was added every minute for $15 \mathrm{~min}$. The cells were then washed three times with PBS and their viability assessed by Trypan blue exclusion (always $>90 \%$ ). The validity of this iodination technique for the lymphocyte cell surface has been established [10].

\section{Down-Regulation of Lymphocyte Insulin Binding}

Before surface labelling, cells were divided into three batches each of approximately $10^{8}$ cells in culture medium, and incubated either with no addition, with $10^{-8} \mathrm{~mol} / \mathrm{l}$ insulin, or with $10^{-6} \mathrm{~mol} / \mathrm{l}$ insulin. After $12 \mathrm{~h}$ at $37^{\circ} \mathrm{C}$, the cells were centrifuged at $600 \times \mathrm{g}$ and given three $30 \mathrm{~min}$ washes in PBS containing $0.1 \%$ bovine serum albumin. This washing technique has been shown to displace residual bound insulin [11]. The cells were then resuspended in PBS $(100 \mathrm{ml})$, aliquots were taken for the measurement of ${ }^{125} \mathrm{I}$-insulin binding, and the remaining cells were suface-labelled.

\section{Insulin Binding}

Insulin was iodinated to a specific activity of $120-140 \mu \mathrm{Ci} / \mu \mathrm{g}$ using carrier-free $\mathrm{Na}^{125} \mathrm{I}$ and a modification of the chloramine $\mathrm{T}$ technique [12]. In the binding assay, a tracer amount of ${ }^{125}$ I-insulin $(10,000 \mathrm{cpm} ; 40 \mathrm{pg})$ was incubated with approximately $10^{6}$ cells in $1 \mathrm{ml}$ of PBS for $45 \mathrm{~min}$ at $24^{\circ} \mathrm{C}$ in triplicate. Parallel incubations contained, in addition, $50 \mathrm{ug}$ of unlabelled insulin in order to determine non-displaceable ('non-specific') radioactivity, which was subsequently subtracted from the total amount bound to give the specific bound value. Cells were precipitated by centrifugation at 4 ${ }^{\circ} \mathrm{C}$ in a Beckman Microfuge, washed once by resuspension in cold PBS, and finally re-precipitated and counted in a gamma spectrometer.

\section{Solubilization of Cells}

After surface labelling, cells were pelleted and stirred for $1 \mathrm{~h}$ at $24^{\circ} \mathrm{C}$ with PBS $(5 \mathrm{ml})$ containing $1 \%(\mathrm{v} / \mathrm{v})$ Triton $\mathrm{X}-100$ and the following serine or thiol protease inhibitors: phenylmethyl sulphonylfluoride $\left(10^{-5} \mathrm{~mol} / \mathrm{l}\right)$ leupeptin $(10 \mu \mathrm{g} / \mathrm{ml})$ and aprotonin $\left(5 \times 10^{2}\right.$ kallikrein inhibitory units $/ \mathrm{ml})$. These protease inhibitors were included in all subsequent procedures. The mixture was then centrifuged at $105,000 \times g$ for $90 \mathrm{~min}$ at $3^{\circ} \mathrm{C}$, and the insoluble pellet discarded. The recovery of solubilized labelled protein was $\sim 90 \%$ and it has been shown previously that labelled protein reflects the content of insulin binding sites [10].

\section{Wheat Germ Lectin Chromatography}

A column of wheat germ lectin-agarose $(0.9 \times 3.0 \mathrm{~cm})$ was washed in turn with $100 \mathrm{ml}$ each of $0.3 \mathrm{~mol} / 1 \mathrm{~N}$-acetyl-D-glucosamine in $50 \mathrm{mmol} / \mathrm{l}$ Hepes; $0.1 \% \mathrm{SDS}$ in $50 \mathrm{mmol} / 1$ Hepes; and a solution containing $0.15 \mathrm{~mol} / 1 \mathrm{NaCl}, 10 \mathrm{mmol} / 1 \mathrm{MgSO}_{4}, 50 \mathrm{mmol} / 1$ Hepes and $0.1 \%$ Triton X-100. Solubilized labelled cells were cycled through the column four times at $24{ }^{\circ} \mathrm{C}$ and the final eluate discarded. The column was washed with $60 \mathrm{ml}$ of $0.15 \mathrm{~mol} / 1 \mathrm{NaCl}$, $10 \mathrm{mmol} / 1 \mathrm{MgSO}_{4}, 50 \mathrm{mmol} / 1$ Hepes, $0.1 \%$ Triton X-100. Bound glycoproteins were eluted by the application of $6 \mathrm{ml}$ of $0.3 \mathrm{~mol} / 1 \mathrm{~N}$ acetyl-D-glucosamine in $50 \mathrm{mmol} / 1$ Hepes containing $0.025 \%$ Triton $\mathrm{X}-100(\mathrm{pH} 7.5)$. The eluate was concentrated fourfold on an Amicon PM-10 membrane, stored at $4{ }^{\circ} \mathrm{C}$, and used for the immunoprecipitation studies within 3 days. We have shown that elution of glycoproteins from wheat germ lectin results in a 20 -fold purification of the insulin receptor with almost complete recovery, and separation of the receptor from insulin degrading activity [13].

\section{Immunoprecipitation of Insulin Receptors}

Wheat germ lectin-purified glycoproteins were immunoprecipitated using receptor auto-antibodies as described previously [10, 14]. The receptor antibodies were obtained from the serum of a patient with the syndrome of severe insulin resistance and acanthosis nigricans $[7,15]$. Their specificity for the insulin receptor has been documented by several criteria [8], including the demonstration that they bind to the same receptor subunits as insulin [9]. IgG fractions from the serum of this patient and from pooled control sera were purified by acid desorption from Protein A-Sepharose [16]. Purified labelled glycoproteins (approximately $5 \times 10^{6} \mathrm{cpm}$, in a volume of $1 \mathrm{ml}$ ) were incubated for $4 \mathrm{~h}$ at $4{ }^{\circ} \mathrm{C}$ with control $\operatorname{IgG}(200 \mu \mathrm{g})$, with or without anti-receptor $\operatorname{IgG}(10 \mu g)$. Sheep anti-human $\operatorname{IgG}$ (titre $2.5 \mathrm{mg} / \mathrm{ml}, 100 \mu \mathrm{l}$, containing protease inhibitors) was added and the incubation allowed to proceed for a further $18 \mathrm{~h}$ at $4{ }^{\circ} \mathrm{C}$. After centrifugation in a Beckman Microfuge, the precipitates were washed twice with $50 \mathrm{mmol} / 1$ Hepes- $0.1 \%$ Triton buffer and immediately counted in a gamma spectrometer. Specific precipitation of ${ }^{125} \mathrm{I}$-receptor was assumed to represent the difference between radioactivity precipitated by anti-receptor $\operatorname{IgG}$ from the patient with insulin resistance and that precipitated or trapped by control $\mathrm{IgG}$.

\section{Sodium Dodecyl Sulphate-Polyacrylamide Gel Electrophoresis and Autoradiography}

The radioactive pellets were solubilized by boiling for $5 \mathrm{~min}$ in $2 \%$ SDS and 5\% mercaptoethanol and electrophoresed [17] in slab gels ( $8 \%$ acrylamide, $2 \mathrm{~mm}$ thickness) under reducing conditions $(1 \%$ mercaptoethanol) in $0.1 \%$ SDS. The following molecular weight standards (Bio-Rad) were used: myosin $(200,000)$, galactosidase $(116,500)$, phosphorylase b $(94,500)$, bovine serum albumin $(68,000)$ and ovalbumin $(43,000)$. Gels were stained overnight in a solution of $50 \%$ methanol, $10 \%$ acetic acid and $0.1 \%$ Coomassie blue, and destained by diffusion in a solution of $5 \%$ methanol, $10 \%$ acetic acid. Autoradiography of dried slab gels was performed at $-70^{\circ} \mathrm{C}$ using an enhancing screen.

\section{Results}

\section{Immunoprecipitation and Analysis of ${ }^{125}$ I-labelled Proteins}

Elution from wheat germ lectin-agarose resulted in an approximately 20 -fold purification of labelled glycoproteins (Fig. 1). In a typical experiment anti-receptor IgG precipitated about $25,000 \mathrm{cpm}$ from $5 \times$ $10^{6} \mathrm{cpm}$ of wheat germ-purified glycoproteins. After washing, non-specific precipitation or trapping by control IgG was $<6 \%$ of total counts precipitated (see also Fig. 2). The specific precipitation by anti-receptor IgG represented $0.02-0.04 \%$ of the crude starting material (Fig. 1), and can be assumed to reflect the initial receptor concentration ( $\sim 1$ part in 5000), since the recoveries from wheat germ lectin $[13,18]$ and after immunoprecipitation [14] are almost complete. Since the insulin binding capacity of solubilized lymphocyte membranes is $1-2 \mathrm{pmol} / \mathrm{mg}[10,18]$ it can be calculated that the native receptor of molecu- 


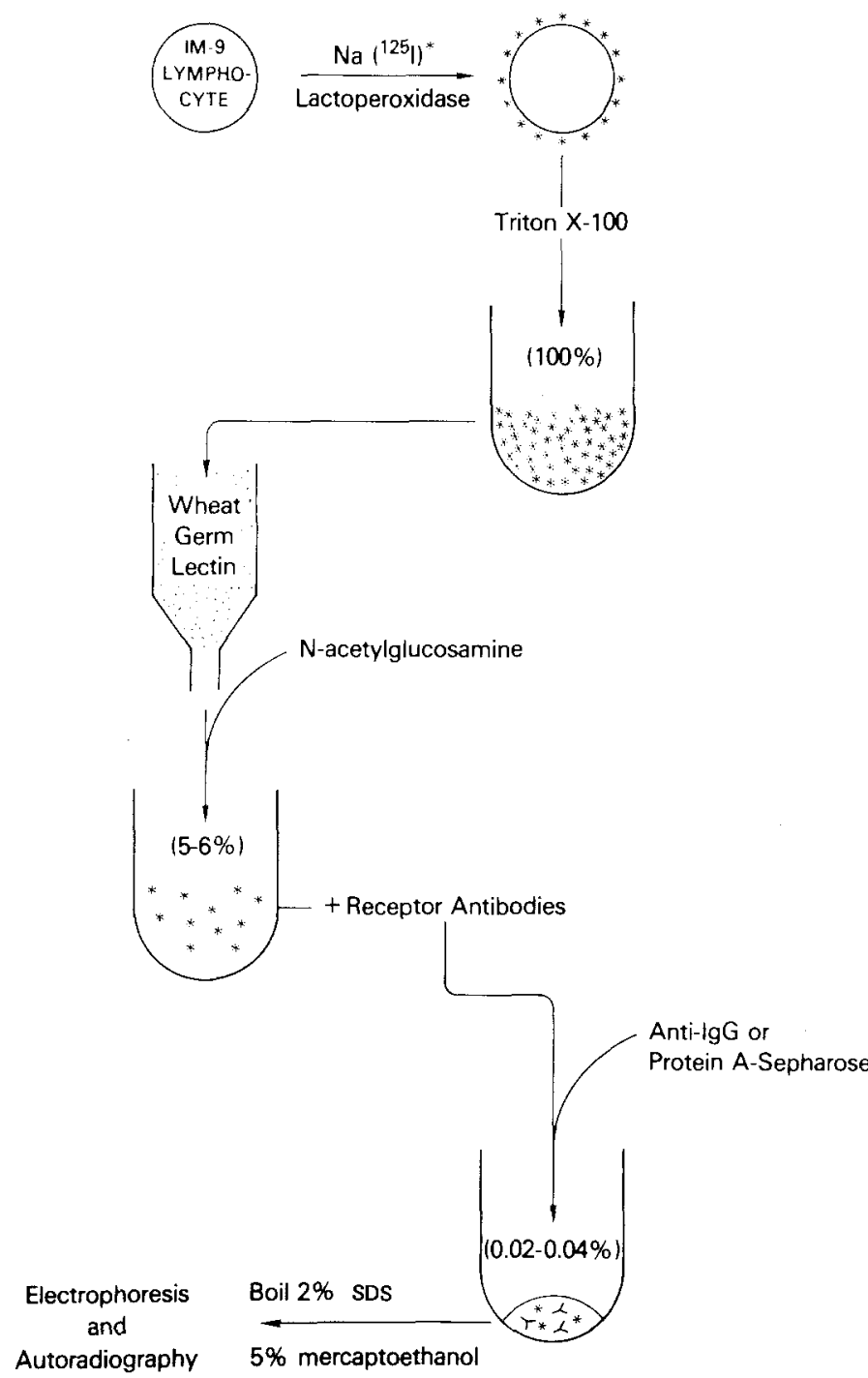

Fig. 1. Scheme for identifying insulin receptor subunits by cell surface labelling and specific immunoprecipitation

lar weight $300-350,000$ has a binding valency of at least 2.

Analysis of the eluate from wheat germ lectin and of the immunoprecipitate by SDS-PAGE and autoradiography, revealed specific precipitation of two major labelled bands with molecular weights of 126,000 and 90,000 , and a minor band of 67,000 (Fig. 2). Excision of the two major bands and counting in a gamma counter revealed that they contained equal amounts of radioactivity. Minor bands of 42,000 and a minor amount of low molecular weight activity $(\sim 20,000)$ were detected in the precipitates with both anti-receptor and control IgG.

When the labelled glycoproteins from the wheat germ lectin column were treated with neuraminidase before immunoprecipitation, there was a small but re-

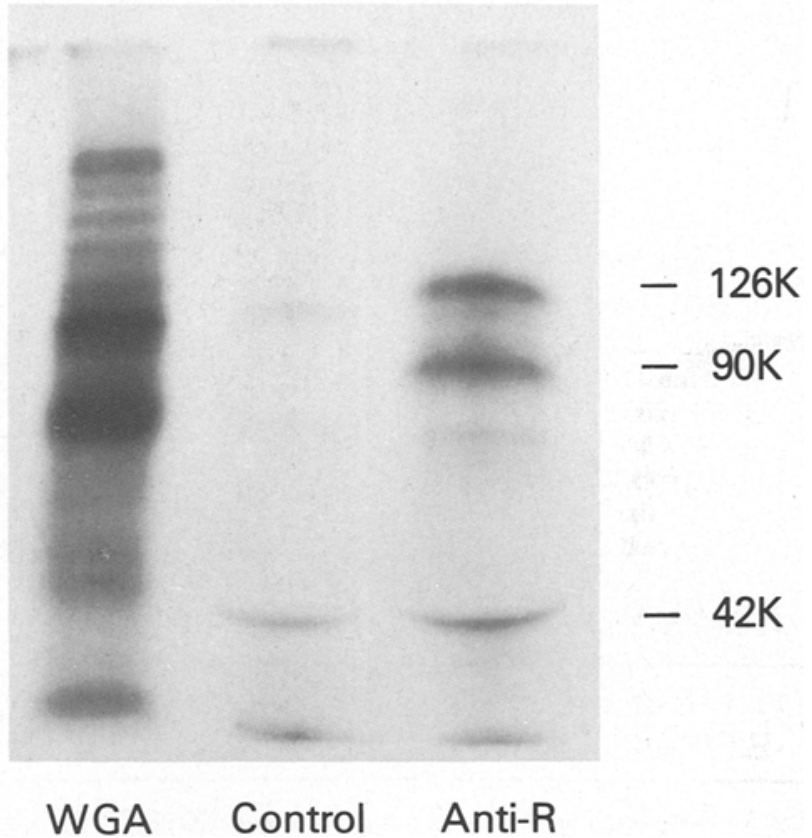

Fig. 2. Autoradiographic identification of insulin receptor subunits separated by SDS-PAGE. Left-hand lane: wheat germ lectin eluate (WGA); middle lane: normal IgG immunoprecipitate (Control); right-hand lane: anti-receptor $\operatorname{IgG}$ immunoprecipitate (Anti-R). The molecular weights of the major specific bands are 126,000 $(126 \mathrm{~K})$ and $90,000(90 \mathrm{~K})$

producible increase in the relative mobilities of both specific bands, their apparent molecular weights decreasing from 126,000 to 120,000 and from 92,000 to 85,000 respectively (not shown).

\section{'Down-Regulation' of Receptor Binding}

Incubation of cells with insulin followed by washing causes a specific time, temperature and dose-dependent decrease in the expression of binding activity, not accounted for by residual receptor occupancy $[11,19$, 20]. When cells were 'down-regulated' in this fashion, before surface labelling, subsequent immunoprecipitation always revealed a decrease in the intensity of both major subunits, compared with control non'down-regulated' cells. This decrease appeared to be proportional to the decrease in insulin binding and was confirmed by excision and counting of the bands. In the experiment shown (Fig. 3), the recoveries of radioactivity in the 126,000 and 90,000 bands respectively, were: A $1555 \mathrm{cpm}$ and $1434 \mathrm{cpm}$; B $624 \mathrm{cpm}$ and $586 \mathrm{cpm} ; \mathrm{C} 140 \mathrm{cpm}$ and $96 \mathrm{cpm}$. It should be emphasised that when surface labelling was performed simply in the presence of excess insulin $\left(10^{-6} \mathrm{~mol} / 1\right.$ insulin preincubated with cells for $10 \mathrm{~min}$ at $37^{\circ} \mathrm{C}$ ), 


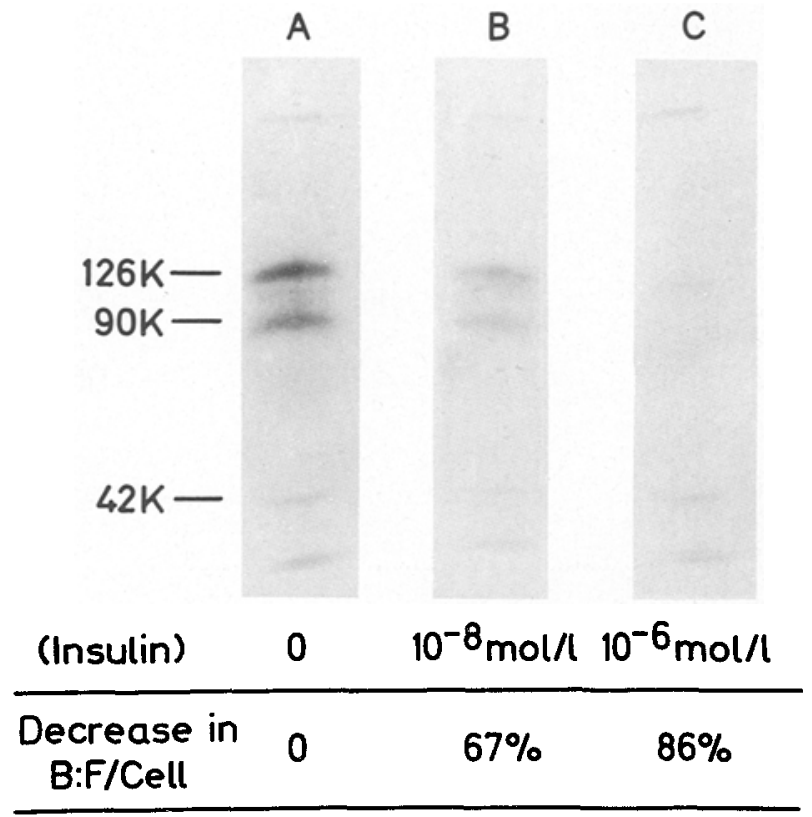

Fig.3. 'Down-regulation' of lymphocyte insulin binding, before ${ }^{125}$ I-surface labelling and immunoprecipitation by antibodies to the insulin receptor. Cultured IM-9 lymphocytes were divided into three equal batches and incubated alone $(A)$, with $10^{-8} \mathrm{~mol} / 1$ insulin $(B)$, or with $10^{-6} \mathrm{~mol} / 1$ insulin $(C)$ for $12 \mathrm{~h}$ at $37^{\circ} \mathrm{C}$, respectively. The cells were then washed three times to remove residual insulin. Specific binding of a tracer concentration of ${ }^{125} \mathrm{I}$-insulin, expressed as the ratio of specifically bound to free radioactivity $(B: F)$ in the three sets of cells, was decreased by $0 \%, 67 \%$ and $86 \%$, respectively. The cells were then treated as shown in Figure 1 . The autoradiographs of SDS-PAGE show disappearance of both the 126,000 and 90,000 receptor subunits concomitant with the 'down-regulation' of specific binding in the intact cells

followed by washing and processing as described, there was no change in the appearance of either subunit.

\section{Discussion}

On the basis of evidence presented here we conclude that the lymphocyte insulin receptor contains 126,000 and 90,000 subunits. The subunits are specifically precipitated by antibodies to the insulin receptor and disappear after 'down-regulation' of binding in intact cells. Both subunits must be surface glycoproteins; they are surface-labelled with ${ }^{125} \mathrm{I}-$, bind to wheat germ lectin, and contain sialic acid because their electrophoretic behaviour is altered by neuraminidase treatment.

The coordinate loss of the subunits after insulininduced 'down-regulation' is strong evidence that 'down-regulation' is not simply due to inactivation of the binding function in situ, but presumably represents loss (e.g. endocytosis) of the subunits from the cell surface. Using a radioimmunoassay for the insulin receptor, we showed that with 'down-regulation' there was a decrease in total cellular immunoreactive receptors [20] and have also reported recently that both subunits can be 'down-regulated' after biosynthetically-labelling them with ${ }^{35} \mathrm{~S}$-methionine [21]. These data are consistant with 'down-regulation' being due to an acceleration of receptor endocytosis and degradation [11].

Other studies have identified an insulin binding site of $125-135,000$ by covalent labelling of membranes with photoreactive ${ }^{125} \mathrm{I}$-insulin derivatives [3-6] or by chemical cross-linking of ${ }^{125}$ I-insulin $[1,2$, 9]. In the studies by Yip et al. [3, 4] and ourselves [9], a second species of 90,000 was also covalently labelled. When the receptor is quantitatively purified using a sequence of either insulin and concanavalin A columns $[5,22]$ or wheat germ lectin and receptor antibody columns [13], major bands of $125-135,000$ and $42-45,000$ are identified by Coomassie blue staining. In addition, after purification of the placental receptor, we detected a minor band of 90,000 whose staining intensity appeared to be inversely proportional to that of the 45,000 band, and suggested therefore that the 90,000 species may be composed of two 45,000 'domains' [13]. These should not be confused with the non-specific band of approximately 42,000 seen in the present experiments. This band runs at the front boundary of the large amount of reduced IgG present and represents a labelled protein recognised by normal human IgG or sheep anti-human IgG, possibly an $F_{c}$ receptor or surface immunoglobulin on the lymphocytes.

The 90,000 subunit has not been uniformly detected by the covalent labelling techniques. In our hands, it was seen when increased concentrations of the chemical cross-linking reagent disuccinimidyl suberate were used [9]. However, even under these conditions, only a minority of the total available insulin receptors in membranes are covalently labelled. The results of cross-linking studies should therefore be interpreted cautiously as they may not reveal the total picture. Although the 90,000 subunit does appear to be an insulin-binding subunit, it cannot be excluded that it is an associated membrane protein with a related role (e.g., an effector molecule for signal transmission or an affinity regulator for the binding site). It is interesting to note that the target size of the functional insulin-binding site determined by radiation inactivation is consistent with a molecular weight of approximately 90,000 [23]. Despite a reasonable consensus as to the subunit composition of the insulin receptor examined in various tissues, the relationship between the subunit components, especially the lower molecular weight forms, remains to be elucidated. Ja- 
cobs et al. [22] have reported that on the basis of peptide mapping the 45,000 species is not a degradation product of the 135,000 species. The $125-135,000$ subunit is therefore probably not composed of 90,000 and 45,000 components.

The subunit sizes found in the present study differ from those we reported previously [10]. In this earlier study, the lymphocyte receptor was resolved into components with molecular weights of $90,000,67,000$, 56,000 and 34,000 ; precipitation of the three larger species was reduced by pre-treatment of ${ }^{125}$ I-labelled, solubilized membranes with $10^{-6} \mathrm{~mol} / 1$ insulin for $16 \mathrm{~h}$ at $4{ }^{\circ} \mathrm{C}$. A band of $125-135,000$ was not clearly defined, but could be seen in some gel patterns even though the $11 \%$ acrylamide rod gels used were not well-suited to resolving molecules of this size. Apart from changing to a more appropriate gel system, we believe that the major reason for these differences, especially the appearance previously of apparently specific, lower molecular weight forms, was the presence of proteolysis. This has been counteracted by modifying the earlier protocol: the labelled lymphocytes were not homogenized to obtain a crude membrane fraction but directly solubilized by gentle stirring in $1 \%$ Triton; protease inhibitors were included in all buffers and in the anti-human IgG serum; and the solubilized cells were first chromatographed on a wheat germ lectin column to purify receptors and remove insulin degrading activity. Proteolysis of the native receptor during solubilization and/or immunoprecipitation is probably due to 'non-specific' proteases, but could possibly also result from the action of receptorrelated proteases or specific processing steps as suggested by Seals and Czech [24]. Careful inspection of other published studies on insulin receptor purification [22] does reveal a number of lower molecular weight components similar to those we reported earlier [10]. Even in the present study, a minor specific band of 67,000 can be seen (Fig. 2). The inhibition of the precipitation of these lower molecular weight components by insulin [10] strongly suggests that they are authentic components of the larger subunits seen in the presence of protease inhibitors. Furthermore, the stoichiometry of insulin binding to the $125-135,000$ subunit is unknown and it could contain more than one insulin binding site.

The functional significance of two major receptor subunits is open to a number of interpretations. Both could contribute to a common binding site region in an analogous fashion to the light and heavy chains in the variable region of immunoglobulin molecules. Alternatively, they may be separate binding sites for one insulin molecule to bind bivalently or for two insulin molecules to bind to classical high and low affin- ity sites. We are currently attempting to determine which of these models applies.

Acknowledgements. We are indebted to Dr. J. Roth without whose support these studies would have not been possible, to Dr. C.R. Kahn for his helpful comments and criticisms, and to Mrs. L. Stafford for secretarial assistance.

\section{References}

1. Pilch PF, Czech MP (1979) Interaction of cross-linking agents with the insulin effector system of isolated fat cells: covalent linkage of ${ }^{125}$ I-insulin to a plasma membrane receptor protein of 140,000 daltons. J Biol Chem 254: 3375-3381

2. Pilch PF, Czech MP (1980) The subunit structure of the high affinity insulin receptor: evidence for a disulfide-linked receptor complex in fat cell and liver plasma membranes. $\mathrm{J}$ Biol Chem 255: 1722-1731

3. Yip CC, Yeung CWT, Moule ML(1978) Photoaffinity labelling of insulin receptor of rat adipocyte plasma membrane. J Biol Chem 253:1743-1745

4. Yip CC, Yeung CWT, Moule ML(1980) Photoaffinity labelling of insulin receptor proteins of liver plasma membrane preparations. Biochemistry 19: 70-76

5. Jacobs S, Hazum E, Shechter Y, Cuatrecasas P (1979) Insulin receptor: covalent labelling and identification of subunits. Proc Natl Acad Sci USA 76:4918-4921

6. Wisher MH, Baron MD, Jones PH, Sonksen PH, Saunders DJ, Thamm P, Brandenburg D (1980) Photoreactive insulin analogues used to characterize the insulin receptor. Biochem Biophys Res Commun 92: 492-498

7. Kahn CR, Flier JS, Bar RS, Archer JA, Gorden P, Martin MM, Roth J (1976) The syndromes of insulin resistance and acanthosis nigricans. Insulin-receptor disorders in man. N Engl J Med 294: 739-745

8. Harrison LC, Kahn CR (1980) Autoantibodies to the insulin receptor: clinical significance and experimental applications. Prog Clin Immunol 4: 107-125

9. Kasuga M, Van Obberghen E, Yamada K, Harrison LC (1981) Autoantibodies against the insulin receptor recognise the insulin binding subunits of an oligomeric receptor. Diabetes 30 : 354-357

10. Lang U, Kahn CR, Harrison LC (1980) The subunit structure of the insulin receptor of the human lymphocyte. Biochemistry 19: $64-70$

11. Kosmakos F, Roth J (1980) Insulin-induced loss of the insulin receptor in IM-9 lymphocytes. A biological process mediated through the insulin receptor. J Biol Chem 255:9860-9869

12. Roth J (1975) Methods for assessing immunologic and biologic properties of iodinated peptide hormones. Methods Enzymol $37: 223-233$

13. Harrison LC, Itin A (1980) Purification of the insulin receptor from human placenta by chromatography on immobilized wheat germ lectin and receptor antibody. J Biol Chem 255: $12066-12072$

14. Harrison LC, Flier JS, Roth J, Karlsson FA, Kahn CR (1979) Immunoprecipitation of the insulin receptor: a sensitive assay for receptor antibodies and a specific technique for receptor purification. J Clin Endocrinol Metab 48: 59-65.

15. Flier JS, Kahn CR, Roth J, Bar RS (1975) Antibodies that impair insulin receptor binding in an unusual diabetic syndrome with severe insulin resistance. Science 190:63-65

16. Goding JW (1978) Use of staphylococcal protein A as an immunological reagent. J Immunol Methods 20:241-253 
17. Laemmli UK (1970) Cleavage of structure proteins during the assembly of the head of bacteriophage T 4. Nature (London) 227:680-685

18. Hedo JA, Harrison LC, Roth J (1981) Binding of insulin receptors to lectins: evidence for common carbohydrate determinants on membrane proteins. Biochemistry $20: 3385-3392$

19. Gavin JR III, Roth J, Neville Jr DM, De Meyts P, Buell DN (1974) Insulin-dependent regulation of insulin receptor concentrations: a direct demonstration in cell culture. Proc Natl Acad Sci (USA) 71: 84-88

20. Harrison LC, Flier JS, Itin A, Kahn CR, Roth J (1979) Radioimmunoassay of the insulin receptor: new probe of receptor structure and function. Science 203: 544-547

21. Van Obberghen E, Kasuga M, LeCam A, Hedo J, Itin A, Harrison LC (1981) Biosynthetic labelling of insulin receptor subunits in the cultured human IM-9 lymphcyte. Proc Natl Acad Sci (USA) 78: 1052-1056
22. Jacobs S, Hazum E, Cuatrecases $P(1980)$ The subunit structure of rat liver insulin receptor: antibodies directed against the insulin-binding subunit. J Biol Chem 255: 6937-6940

23. Harmon JT, Kahn CR, Kempner ES, Schlegel W (1980) Characterization of the insulin receptor in its membrane environment by radiation inactivation. J Biol Chem 255:3412-3419

24. Seals JR, Czech MP (1980) Evidence that insulin activates an intrinsic plasma membrane protease in generating a secondary chemical mediator. J Biol Chem 255: 6529-6531

Received: 6 May 1981

and in revised form: 28 August 1981

Len C.Harrison

The Endocrine Laboratory

Royal Melbourne Hospital

Victoria 3050, Australia 